RFP-2573

January 17,1977

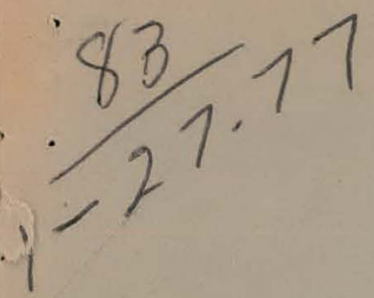

\title{
LIGHT WATER REACTOR FUEL RECYCLE PROGRAM PLUTONIUM NITRATE-TO-OXIDE CONVERSION PROJECT
}

PROGRESS REPORT, MAY-JUNE 1976

\author{
George D. Lehmkuhl
}

Chemistry Research and Development PROCESS CHEMISTRY AND ENGINEERING GROUP

\author{
Work performed under 189 No. F-AL-10-001 \\ for the \\ Savannah River Operations Office
}

U. S. Energy Research and Development Administration

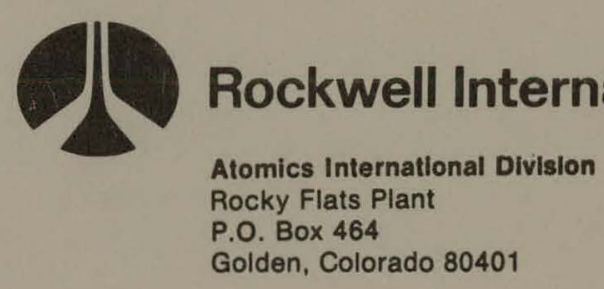

U.S. ENERGY RESEARCH AND DEVELOPMENT ADMINISTRATION CONTRACT EY-76-C-04-3533 


\section{DISCLAIMER}

This report was prepared as an account of work sponsored by an agency of the United States Government. Neither the United States Government nor any agency Thereof, nor any of their employees, makes any warranty, express or implied, or assumes any legal liability or responsibility for the accuracy, completeness, or usefulness of any information, apparatus, product, or process disclosed, or represents that its use would not infringe privately owned rights. Reference herein to any specific commercial product, process, or service by trade name, trademark, manufacturer, or otherwise does not necessarily constitute or imply its endorsement, recommendation, or favoring by the United States Government or any agency thereof. The views and opinions of authors expressed herein do not necessarily state or reflect those of the United States Government or any agency thereof. 


\section{DISCLAIMER}

Portions of this document may be illegible in electronic image products. Images are produced from the best available original document. 


\section{LEGAL NOTICE}

This report was prepared as an account of work sponsored by the United States Government. Neither the United States nor the Encrgy Kesearch and Development Administration, nor any of their employees, nor any of their contractors, subcontractors, or their employees, makes any warranty, expressed or implied, or assumes any legal liability or responsibility for the accuracy, completeness or usefulness of any information, apparatus, product or process disclosed, or represents that its use would not infringe privately owned rights.

Printed in the United States of America Available from the

National Technical Information Service

U. S. Department of Commerce

Springfield, Virginia 22161

Price: Printed Copy $\$ 4.50$ Microfiche $\$ 3.00$

Price Is Subject to Change Without Notice 


\title{
LIGHT WATER REACTOR FUEL RECYCLE PROGRAM PLUTONIUM NITRATE-TO-OXIDE CONVERSION PROJECT PROGRESS REPORT, MAY-JUNE 1976
}

\author{
George D. Lehmkuhl
}

\author{
Chemistry Research and Development \\ PROCESS CHEMISTRY AND ENGINEERING GROUP
}

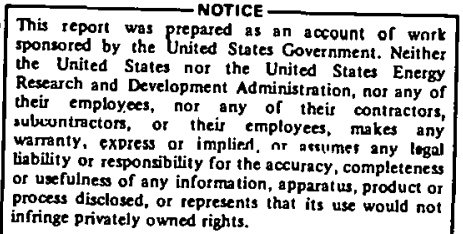

ROCKWELL INTERNATIONAL

ATOMICS INTERNATIONAL DIVISION

ROCKY FLATS PLANT

P.O. BOX 464

GOLDEN, COLORADO 80401

Prepared under Contract EY-76-C-04-3533

for the

Albuquerque Operations Office

U.S. Energy Research and Development Administration 
THIS PAGE

WAS INTENTIONALLY

LEFT BLANK 


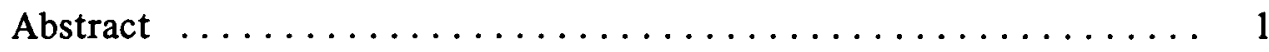

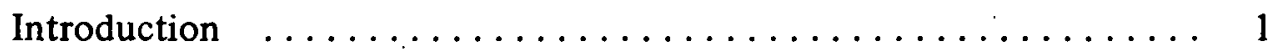

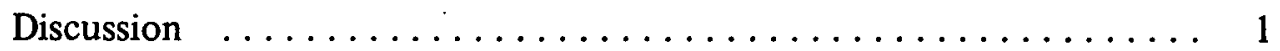

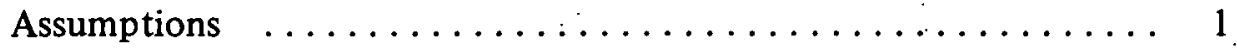

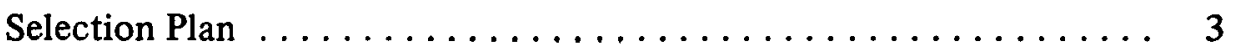

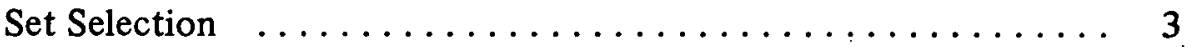

Primary Process Selection $\quad \ldots \ldots \ldots \ldots \ldots \ldots \ldots \ldots$

1. Weighting Procedure $\ldots \ldots \ldots \ldots \ldots \ldots \ldots \ldots$

2. Weighting Table $\ldots \ldots \ldots \ldots \ldots \ldots \ldots \ldots \ldots \ldots$

3. Process Evaluation $\ldots \ldots \ldots \ldots \ldots \ldots \ldots \ldots \ldots \ldots \ldots$

Selection Criteria ........................ 4

Text of Criteria $\ldots \ldots \ldots \ldots \ldots \ldots \ldots \ldots \ldots \ldots \ldots \ldots \ldots \ldots \ldots \ldots$

1. Single Train Capacity $\ldots \ldots \ldots \ldots \ldots \ldots \ldots \ldots \ldots 4$

2. Feed Preparation $\ldots \ldots \ldots \ldots \ldots \ldots \ldots \ldots \ldots$

3. Recycle Streains $\ldots \ldots \ldots \ldots \ldots \ldots \ldots \ldots \ldots \ldots \ldots$

4. Waste Streams $\ldots \ldots \ldots \ldots \ldots \ldots \ldots \ldots \ldots \ldots$

5. Operating Experience $\ldots \ldots \ldots \ldots \ldots \ldots \ldots \ldots$

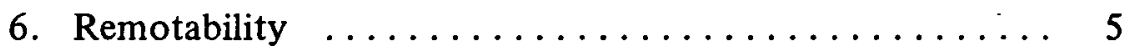

7. Maintenance..................... 5

8. Environment and Safety.............. 5

9. Inventory Requircments $\ldots \ldots \ldots \ldots \ldots \ldots \ldots \ldots$ 
RFP-2573

10. Compatibility of Product with Subsequent Processing .... . 5

11. Relative Energy Consumption $\ldots \ldots \ldots \ldots \ldots \ldots \ldots$

Information Packages $\ldots \ldots \ldots \ldots \ldots \ldots \ldots \ldots \ldots$

Conclusions $\ldots \ldots \ldots \ldots \ldots \ldots \ldots \ldots \ldots \ldots \ldots \ldots \ldots \ldots \ldots \ldots \ldots$ 


\section{ACK N O W L D G M E N T S}

Appreciation is expressed, for the preparation of this report, to the following members of the PNO Project Team: David H. Neal, Robert L. Riegel,

Kenneth R. Souply, Robert Southworth III, and Warren I. Yamada. 
RFP-2573

\section{THIS PAGE \\ WAS INTENTIONALLY \\ LEFT BLANK}




\title{
LIGHT WATER REACTOR FUEL RECYCLE PROGRAM \\ PLUTONIUM NITRATE-TO-OXIDE CONVERSION PROJECT
}

PROGRESS REPORT, MAY-JUNE 1976

\author{
George D. Lehmkuhl
}

\begin{abstract}
Work is being done at the Rocky Flats Plant under contract from the Savannah River Operations Office (SROO) of the U.S. Energy Research and Development Administration (ERDA) to critically analyze and evaluate existing technology for converting plutonium nitrate to plutonium oxide, and to recommend flow sheets and equipment for this process.
\end{abstract}

This report details a plan for selecting the most suitable process using presently developed technology. In addition, the scope-defining assumptions and the criteria to be used for comparing the processes are defined. The criteria will be used to select a primary and several alternative processes for conversion of plutonium nitrate to plutonium oxide in reprocessing light water reactor (LWR) fuel.

\section{INTRODUCTION}

A defined set of criteria is required to meaningfully. compare the merits of several processes for convcrting plutonium nitrate to plutonium oxide. In order to prepare process flow sheets, material balances, and equipment diagranrs, assumptions which define the scope and limits of the process must be made. The scope not only must limit unnecessary effort by keeping the design from ranging too far afield, but it must also include all work reasonably expected to be a part of the individual process unit. The sections that follow list the scope-defining assumptions and process-comparison criteria to be used for the LWR Fuel Recycle Program, Plutonium Nitrate-to-Oxide (PNO) Conversion Project. As work progresses and information is developed, modification of these assumptions or criteria may be necessary.

\section{DISCUSSION}

\section{Assumptions:}

The following assumptions are based on a PNO Conversion Project scope which includes plutonium processing only. If a mixed uranium/plutonium oxide must be produced (for reasons such as safeguards), the project scope will require redefining.

The required through-put for the reprocessing plant is 100 kilograms $(\mathrm{kg})$ of plutonium per day. This basis allows easy scaling to other rates. The 100$\mathrm{kg}$ per day rate is based on the following factors: A 1500-metric tonne per year fuel recycle facility, feed containing 1 percent plutonium, an average operation of 300 days per year, and a surge daily rate of twice the average.

The PNO Conversion Unit feedstock consists of plutonium nitrate solution from the Purex process. Typical feedstock specifications are listed in Table $\mathrm{I}$.

The product specifications are listed in Table II. These specifications were taken from the Barnwell Nuclear Fuel Plant docket No. 50332-38, Preliminary Safety Analysis Report license application, Table 4.1-2, Page 4-4. These specifications are not as stringent as those set for Fast Flux Test Facility fuel $^{1}$, or those set by Alphachemie und Metallurgie, West Germany. ${ }^{2}$

A waste-treatment plant exists at the fuel recycle facility. Liquid wastes, below throw-away limits,

\footnotetext{
1 "Fast Flux Text Facility Ceremac Grade Plutonium Dioxide." Reactor Development and Technology Standard U. S. Atomic Energy Commission, Washington, D. C. E 13-IT. June 1971.

${ }^{2}$ K. D. Kuhn and J. Nowak. "Standard Specification of Plutonium Dioxide for Fabrication of Mixed Oxide Rods." Spezifikation No. 7.033. Alphachemie und Metallurgie, Gmbh., West Germany. August 1972.
} 
RFP-2573

TABLE I. Typical Feedstock Specifications.

\begin{tabular}{|c|c|}
\hline Property & Concentration \\
\hline Plutonium & 250 grams per litre \\
\hline Nitric Acid & 2 to 10 molar \\
\hline Uranium & $<10,000$ parts per million parts of plutonium \\
\hline Other Metals & $<10,000$ \\
\hline Sulfur & $<1000$ \\
\hline Halogens & $<150$ \\
\hline $\begin{array}{c}\text { Fission Products } \\
\text { Gamma } \\
\text { Emitting }\end{array}$ & $<80$ microcuries per gram of plutonium \\
\hline $\begin{array}{l}\text { Zirconium- } \\
\quad \text { Niobium } 95\end{array}$ & $<10$ microcuries per gram of plutonium \\
\hline
\end{tabular}

TABLE II. Plutonium Oxide Specifications.

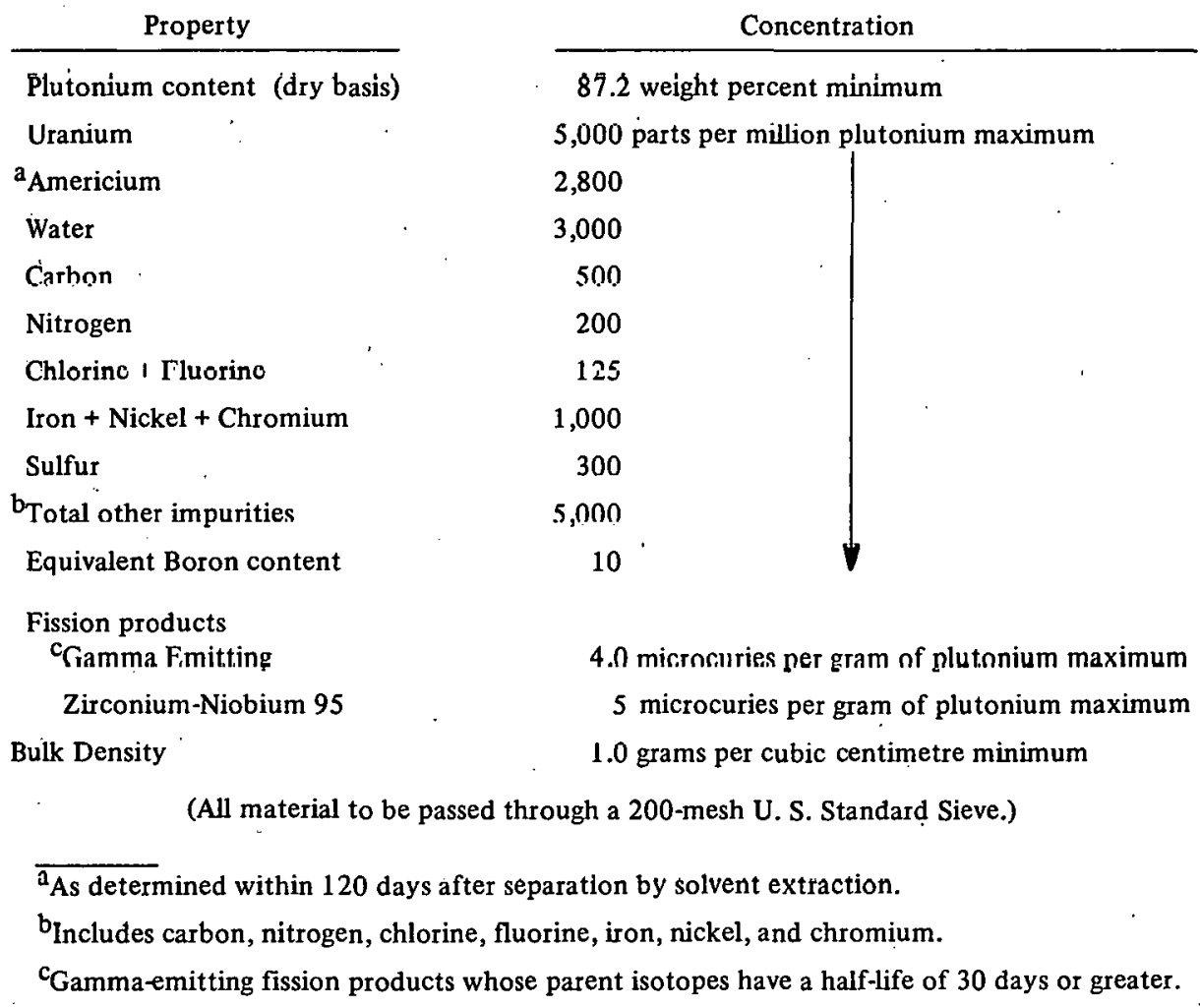

will be transferred to the waste-treatment plant by a piping system. Throw-away limits are defined as: $1 \times 10^{-3}$ grams of plutonium per litre of liquid.

Liquid waste and recycle streams in excess of throw-away limits will be decontaminated using equipment included in the denitration unit before transfer to the waste-treatment plant.

Solid recycle and waste streams will be processed in one of two ways. Recycle plutonium oxide will be sent to the dissolution unit. (A special plutonium 
oxide dissolution module may be necessary if halogens are to be kept out of the main process stream. Designers of the dissolution unit should be aware of this.) Line-generated solid wastes will be transferred to solid waste disposal.

Off-gas streams will be processed using equipment located in the denitration unit before release to the plant filter plenums.

All required utilities will be provided. Resources which can be recovered (such as nitric acid) will be transferred by the appropriate means to a utility system. Where needed for design calculations, standard plant values will be assumed for utilities (e.g., cooling water available at $15.5^{\circ} \mathrm{C}$, returned at $26.6{ }^{\circ} \mathrm{C}$ ).

Process equipment used to handle primary plutonium streams must be remote from operators; no hands on operation. A primary plutonium stream is defined as one which requires protection from radiation hazards. The plant facility should be designed so as to limit the whole body dose to 1 rem per year, as directed in the Atomic Energy Commission Manual, Appendix 6301, Part II, Section H, "Minimum Design Criteria for New Plutonium Facilities."

\section{Selection Plan:}

The PNO Conversion Project Team will select the primary and secondary processes for recommendation by the following general procedure. First, the set of processes having a reasonable possibility of successful commercial application will be chosen. Then, this set will be evaluated to choose the primary process that presents the strongest potential for commercial application.

\section{Set Selection}

The set of potential processes to be evaluated for commercial application will be chosen by surveying literature, other ERDA installations, and industrial plants and laboratories. All processes discovered will then be evaluated against a gate criterion for admittance to the set for further evaluation. The only processes selected for further consideration will be those having at least pilot-plant operating experience. The basis for this criterion follows directly from the project charter to use proven technology.

\section{Primary Process Selection}

Each criterion will be weighted by the procedure described below; then, each candidate process will be rated with respect to each criterion on a scale of 1 to 10 . The rating will be multiplied by the weighting factor, and the weight-rating products will be summed for each process. The process with the greatest sum will be selected as the primary process.

1. Weighting Procedure. The PNO Conversion Project Team will assign recommended weights to the criteria. A listing of the criteria, with the assigned weights, will be circulated to those ERDA and industrial personnel involved. They will have the opportunity to suggest changes in the set of criteria, or to suggest different weighting. The respondent weights will be used to obtain a consensus.

2. Weighting Table. An example of the proposed weighting and rating procedure is shown in Table III.

By using this procedure, Process I would be selected as the primary process. Subjective weighting of the criteria is necessary to preclude all the criteria from being equally weighted. Obviously, some criteria are more important than others and should be weighted more heavily. This notion, of course, does not preclude some criteria receiving equal weighting.

3. Process Evaluation. The PNO Conversion Project Team will evaluate the candidate processes by the following method. Process flowsheets will be generated for each process. Material and energy balances will be developed for at least the major components and major equipment items. Each process will then be evaluated on the basis of how well it satisfies each criterion. Each process will be assigned a rating of 1 to 10 on the basis of the evaluation, and this rating will be used in the evaluation table to select the primary process. 
TABLE III. Weighting and Rating Procedure.

\begin{tabular}{|c|c|c|c|c|c|}
\hline \multirow[b]{3}{*}{ Criterion } & \multirow{3}{*}{$\begin{array}{c}\text { Weighting } \\
\text { Factor }\end{array}$} & \multicolumn{4}{|c|}{ Process Evaluations } \\
\hline & & \multicolumn{2}{|c|}{ Process I } & \multicolumn{2}{|c|}{ Process II } \\
\hline & & rating & product & rating & product \\
\hline No. 1 & 5 & 4 & 20 & 5 & 25 \\
\hline No. 2 & 3 & 8 & 24 & 3 & 9 \\
\hline No. 3 & 4 & 7 & 28 & 6 & 24 \\
\hline No. 4 & 7 & 3 & 21 & 3 & 21 \\
\hline No. 5 & 6 & 6 & 36 & 5 & 30 \\
\hline Totals & & & 129 & & 109 \\
\hline
\end{tabular}

TABLE IV. Summary of Criteria and Weighting Factors.

\begin{tabular}{lcc}
\multicolumn{1}{c}{ Criteria } & Weighting Factor \\
\cline { 3 - 3 } Single train capacity & 5 \\
Feed preparation & 2.5 \\
Recycle streums & 4 \\
Waste streams & 7 \\
Operating experience & 6 \\
Remotability & 7 \\
Maintenance & 8 \\
Fnvirnnment and safety & 10 \\
Inventory requirements & 2 \\
Compatibility of product & 9 \\
$\quad$ with subsequent processing & \\
Rclativc cncrgy consumption & 1
\end{tabular}

\section{Selection Criteria:}

Table IV summarizes the selection criteria and lists their associated weighting factors.

\section{Text of Criteria}

The major fixed-cost for the reprocessing plant is the hardened building rather than the processing equipment. Building standards, such as those for earthquake, tornado, and low radiation exposure to personnel, require an extremely substantial structure. In the text below, increased "hardened processing area" indicates increased costs resulting from the increase in building area required. An increase in the possibility of radiation exposure and in the number of operating personnel required is related to an increase in process area.

1. Single Train Capacity. The full through-put of the plant should be handled by as few process trains as possible. A single train is preferred. Fewer trains generally reduce equipment failures, leaks, maintenance, capital and operating costs, and hardened processing area. The capacity of each train can be limited by both process and non-process constraints. A batch process typically requires at least two trains to achieve continuous through-put and avoid excessive feedstock inventories. A continuous proçcss usually requirçs largcr recycle stıeans and muderately large interstage storage. The principle non-process constraint is criticality limits. Certain equipment items will need to be redundant; for example, any rotating equipment is usually a high maintenance item. Although redundancy reduces the difference between the single and the multiple train, the difference may still be large.

2. Feed Preparation. Feed preparation includes any processing prior to the denitration itself. Such processing could include: purification, dilution, concentration, nixing, and $\mathrm{pH}$ and valence adjustment. More extensive feed pieparation incleases prucessing custs and requires more hardened processing a rea. Minimum feed preparation is preferred.

3. Recycle Streame. Every candidate procecs will probably have some recycle strcams. Rccycling, in itself, does not introduce problems. However, recycle which requires large flows and storage, or which requires several processing steps to return it to the main process flow, does increase processing costs and, therefore, represents increased hardened processing area. Differentiation among processes must be made on the consequences of recycle and not on whcthcr an individual candidate process has one or several recycle streams.

4. Waste Streams. Every candidate process will probably require some processing of wastes 
before discharge to the waste treatment plant or to the filter plenums. Scrubbing of offgasses may be required. A process which requires a high level of waste treatment will have increased processing costs and will . require increased hardened processing area. The preferred process will have a minimum waste-processing requirement.

5. Operating Experience. The process having the largest amount of pilot plant, production demonstration, and production scale operating experience is given the highest rating under this criterion. All processes in the set under consideration have some operating experience as established by the initial set selection.

6. Remotability. The PNO Conversion Process must be remoted because of the radiation levels of the materials involved. Remoting makes operating the equipment more difficult, and increases the need for instrumentation. Therefore, the process most easily remoted is given the highest rating. Any remotedequipment operating experience also increases the rating of a process.

7. Maintenance. Maintenance is a serious problem because of the degree of remoting and amount of radiation shielding necessary. Processes with a minimum of equipment items, moving parts, and instrumentation receive the highest rating. Again, operating experience, is an important indicator of the degree-of-maintenance required.

8. Environment and Safety. The use of corrosive, toxic, or explosive chemicals (including combinations of chemicals and operating conditions) should be minimized. The use of these chemicals may cause equipment failure, may cause the release of toxic vapors which must be processed by off-gas equipment, or may cause releases of radiation materials, which, in turn, may result in personal injury.

9. Inventory Requirements. Processes requiring large in-process or interstage inventories will require larger hardened processing area. Large inventories also cause accountability problems. Therefore, minimum inventory is preferred.

10. Compatability of Product with Subsequent Processing. The product of any process must be in a readily-usable condition for downstream units without appreciable reprocessing. The oxide product from the PNO Conversion Process must be readily usable by the fuel fabricator and must be capable of being directly reprocessed.

11. Relative Energy Consumption. Efficiency, in terms of energy consumption, is important. However, it is impossible to evaluate the energy consumption in detail until exact equipment specifications have been set. Only gross differences in energy requirements can be readily identified, and only these gross differences are of consequence. A process with minimum energy consumption is preferred; but it is unlikely that energy consumption will exhibit large differences between various processes.

\section{Information Packages:}

Information packages will be prepared on the processes which pass the set selection criterion. These packages will include the following information: process flow sheet and material balance; equipment flow sheet; history of research and operation of the process at ERDA and private sites; a process description; comprehensive reference listing of literature pertinent to the process; listing of advantages and disadvantages of the process as expressed by persons contacted, the literature, or the project team; discussion of how the process fits the process selection criteria and the process rating system; listing and discussion of research and development that should be done on the process; and any other items deemed pertinent to the process.

\section{CONCLUSIONS}

Under a contract from the Savannah River Operations Uffice of ERDA, Rocky Flats Plant will analyze and evaluate existing technology for converting plutonium nitrate to plutonium oxide in reprocessing LWR fuel. The process exhibiting the highest degree of efficiency for commercial application will be selected and full engineering criteria will be supplied to Savannah River Laboratory. 
RFP-2573

\section{THIS PAGE WAS INTENTIONALLY LEFT BLANK}

